\title{
Pre-project evaluations of All-Russian Exhibition Center landscape park ponds condition
}

\author{
Lyudmila Frishter ${ }^{1,1}$ \\ ${ }^{1}$ Moscow State University of Civil Engineering, Yaroslavskoe shosse, 26, Moscow, 129337, Russia
}

\begin{abstract}
Modeling and planning of Moscow urban development sustainability affect many urban infrastructures, including social, transport, engineering ones, as well as modern level of land improvement. Modern architectural and design possibilities in urban environment planning are implemented in a large-scale reconstruction project of the All-Russian Exhibition Center (VVC). The reconstruction of the VVC complex in Moscow includes creation of artificial urban landscape with pronounced nature of exhibition complex. VVC landscape complex includes a cascade of ponds, hydraulic engineering system based on the Kamenka river ponds with fountains and decorative pools. This article considers a pre-project stage of pond cascade inspection, technical condition of hydraulic engineering structures, ponds silting. The inspection is aimed at obtaining a project evaluation of pond cascade hydraulic engineering structures technical condition, including evaluation of possibility for further operation, reinforcement or restoration of the structures. Historical background of "VSHV-VDNH-VVC" - Zone "VDNH landscape park" foundation is also given. History of exhibition complex arrangement and development is considered from the perspective of architectural and design conditionality and modeling by temporal social demand. The article also includes brief historical background of the park complex and hydraulic structure operation projects. Following the pre-project stage of pond cascade hydraulic engineering structures inspection, a conclusion on the condition of reconstructed sightseeing attraction "VSHV-VDNH-VVC" Zone "VDNH landscape park" is given.
\end{abstract}

\section{Introduction}

Artificial urban landscape specific to exhibition complex is currently being developed in Moscow megalopolis on the VVC complex territory [1-4]. The modern concept of park territory reconstruction has been developed by the world's leading architect Mishel Pena from France. The landscape park is a unique complex, which includes five natural zones and a large walking alley of $5.5 \mathrm{~km}$ long based on the Ring road which has existed here since the 1950s.

\footnotetext{
${ }^{1}$ Corresponding author: 1frishter@mail.ru
} 
The VDNH landscape park is created on the basis of the Kamenka river ponds with fountains, decorative pools and functioning hydraulic engineering system. The ponds and hydraulic engineering structures as part of the landscape park are subject to environmental protection. The VVC ponds require immediate cleaning as well as inspection of pond cascade hydraulic structures technical condition. Without cleaning the concentration of pollutants will grow annually which will result in negative consequences for both visitors and the environment. The technical inspection of the hydraulic structures [5-9] should determine service life of the structures built in the 50 s of the last century.

The pre-project stage of landscape park designing [10-12] including pond cascade hydraulic engineering structures requires comprehensive inspection of dams and spillways technical condition, condition of the banks, pond bottom silting, which determines the research subject.

This paper is aimed at carrying out pre-project evaluations of the pond cascade hydraulic engineering structures technical condition to model and design the VDNH landscape park, including evaluation of further service life, need to reinforce or restore the hydraulic engineering structures.

\section{Historical background}

Sightseeing environment "VSHV-VDNH-VVC" - zone "VDNH landscape park" at the address: 119 Mira avenue, Moscow, is a holistic architectural form of cultural and historical significance $[1-3,13]$. The analysis of historical and cultural context of VVC complex environment arrangement and existence characterizes spiritual and practical activities of urban community and temporal social demands. Changes in VDNH architectural complexes $[1-3,12,13]$ reveal priorities in development of society in different time periods. In spite of all changes in architectural forms and their conditionality, the principles of firmitas, utilitas, venustas remain unchanged.

\subsection{VSHV-VDNH-VVC: brief historical background}

The All-Union Agricultural Exhibition (VSHV) was opened on August 1, 1954 as a permanent one [1-4]. The exhibition mission was to demonstrate achievements of socialist community agriculture, to exchange, spread and study advanced agricultural production experience, which is still conformable to the current trends - development, spread and transfer of innovative technologies. Being conformable to the time of construction, the VSHV exhibition was distinguished by its scale and size, wealth of architecture and decoration, number of exhibits and exhibitors.

The exhibition layout principle was consistent deployment of the display based on clear differentiation and design of various sections of the territory [1-4]. A special feature of the exhibition layout and development was showiness of overall compositional solution and integrity of architectural complex.

The VSHV - VDNH exhibition was a part of Moscow reconstruction in the 1950s 1960 s, which was aimed at combining architecture with the natural landscape, coherence with the general appearance of Moscow. The Exhibition construction idea was to create a kind of gaily decorated and festive district of national economic importance, which clearly reflected economic and cultural flowering.

The architecture geometry was determined by satisfying social needs in all complexity through the use of the best means $[1-2,13]$.

The significant changes in the economic paradigm of society in the 1990s and changes in social demands led to a decrease of public interests in exhibition complex development. VDNH displays fell into decay, no new architectural sites were constructed. 
At present, the exhibition zone needs to be reconstructed, the new understanding of landscape architecture and design in the city, including artistic and aesthetic design of open urban spaces, taking into account historical significance and cultural identity is highly required.

The modern plan for VVC reconstruction and development up to 2034 is conditioned by new social demands: environmental compatibility, practicability, technological effectiveness, educational opportunity, entertainment, adaptedness for visit by mobility impaired people $[11,12]$. The exhibition functional objectives remain the same: a largescale exhibition, representative, trade, information, logistics, transport center, a place for family and youth recreation.

\subsection{VDNH landscape park: brief historical background}

The VVC territory is a part of the preexisting extensive forest area of the Ostankino manor owned by count N.P. Sheremetyev in the $18^{\text {th }}$ century. In the late 1780 's, N.P. Sheremetyev built a new palace in the estate, redeveloped and expanded the old park. Six large and small ponds were arranged on the Kamenka river. This part of the park was designed as per the project of serf architect P.I. Argunov in English landscape style with alleys leading to oak woods and hunting lands. Ornamental trees with bushes were planted in the park. In the 30s of the $19^{\text {th }}$ century the "golden" age of nobility estates came to an end, the park lands fell into decay, country cottages were built, the park became a place for townspeople walks.

By 1917, most of the estate territory had preserved a considerable forest area, although it was thinned out. In the $20^{\text {th }}$ century the park lands were no longer a distant suburb of Moscow, but a museum complex, included in urban development area.

Considering a huge value of the natural forest, architects assign its main territory to the modern master plan of Moscow as a park site. Currently, a landscape park, which includes the cascade of ponds with hydraulic engineering structures, is being developed on the VVC territory.

\section{Technical condition of the pond cascade hydraulic engineering structures}

Cascade of the ponds No. 1 - No. 5 includes four dams between the ponds maintaining pressure between the head and tail waters, five spillways of different types for discharge into the tail water.

The spillways for the dams on the Kamenka river were built in 1939. The spillways were originally made of wood with wooden decking on the wooden piles. Examinations conducted in 1948 revealed weak operation capacity of decayed wooden piles and reinforced concrete spillways were proposed.

The ponds were reconstructed in 1950-54. The wooden spillways were dismantled to the wooden piles and reinforced concrete spillways were erected on the survived base.

The ponds had been reconstructed, restored and upgraded from 1979 to 1982 . In 1981 82 , as-built drawings for restoration of the dams, spillway elements, bank protections, as well as construction of a berth on the pond No. 2 and restoration of ponds and dams functioning were developed.

In 2014, due to poor technical condition, a spillway on the dam between the ponds No. 1 and No. 2 was replaced, and bank protections in certain areas of the ponds were also repaired.

The pre-project inspection of the dams and spillway structures [5-9, 14, 15] are aimed at describing the structures, including photographic evidence of defects, damages and 
structural deterioration, analysis of structure projects developed for a long period of over 75 years of operation, including structures and ponds reconstruction and upgrade projects.

The technical condition of the inspected hydraulic engineering structures is evaluated as normal, satisfactory, unsatisfactory and unacceptable [14-18]. According to terminology of the Russian register of hydraulic engineering structures, the safety level of structures operation is evaluated as normal, low, unsatisfactory and dangerous. Inspected hydraulic engineering structures are of Class IV, structures criticality rating is normal [9, 17-18].

\subsection{Pond cascade dams}

The pond cascade has four dams: No. 1 between the ponds 1 and 2, No. 2 between the ponds 2 and 3, No. 3 between the ponds 3 and 4, No. 4 between the ponds 4 and 5. The dams are earth, homogeneous, of $9 \mathrm{~m}$ to $5.5 \mathrm{~m}$ high, their head is low ranging from $6 \mathrm{~m}$ to $2.2 \mathrm{~m}$.

Freeboard for all dams over the full reservoir level is sufficient from 2.45 to $1.5 \mathrm{~m}$. The dam crest is used for pedestrian walking and service vehicles passage. The road along the crest is $7 \mathrm{~m}-7.5 \mathrm{~m}$ wide. Dam upper and lower slopes are fixed by grassing.

Silting (reeds, grass) is observed in the dam tail water area. Fig.1a shows silting area of the pond No.3 viewed from the dam No. 2 lower slope near the bottom outlet.

Archival materials contain a scheme of ponds silting and pond bed cleaning project dated 1979. Current location of silting areas coincides with those shown in the pond silting scheme of 1979, which characterizes temporal stability of the pond ecosystem.

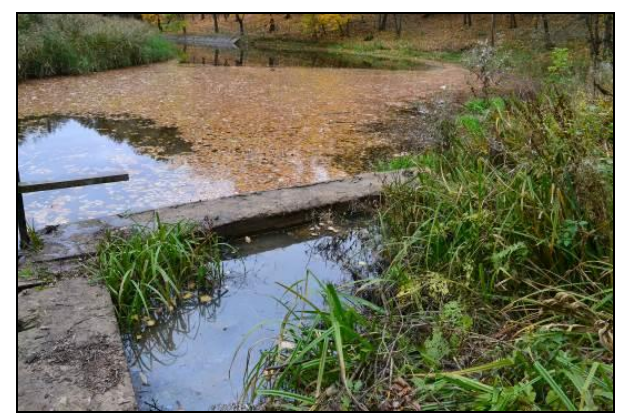

a)

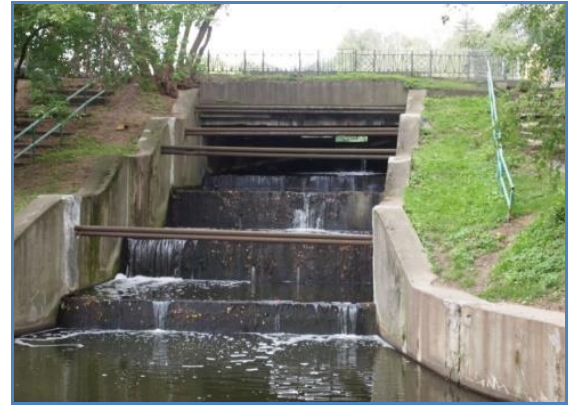

b)

Fig.1. a) Fragments of the dam No. 2 lower slope. Scour at the bottom outlet wall, Staged water outlet of the dam No.3 spillway viewed from the tail water.

\subsection{Pond spillways}

\subsubsection{The first stage of cascade}

The first stage of cascade between the ponds No. 1 and No. 2 includes an earth dam and low-head overflow spillway 1-2.

The spillway 1-2 between the ponds No. 1 and No. 2 is located in the dam body and adjoins the high right bank. The spillway is made of cast in-situ reinforced concrete.

When studying archival materials, documents on previous spillway projects have been found: in wood and reinforced concrete design; no materials on modern spillway 1-2 have been found. 
A feeder channel on the pond No. 1 side is small. The spillway head wall (transit zone) in the form of a horizontal reinforced concrete slab has one span of $4.3 \mathrm{~m}$ wide and $4.5 \mathrm{~m}$ long. The head wall span is covered with flat wooden sluice boards, debris screens are available. Near the abutment adjacent to the dam, there is a dumped riprap used as drainage.

\subsubsection{The second stage of cascade}

The second stage of cascade between the pond No. 2 and No. 3 includes an earth dam and a shaft spillway with bottom outlet.

The archival materials contain a master plan of the structures built in 1950 and a technical project for restoration of the pond No. 2, which shows a shaft spillway and bottom outlet, dam No. 2 between the ponds No. 2 and No. 3, a flood spillway which has not survived to date. No documentation on the spillway 2-3 in its current state has been found.

The main part of the reinforced concrete shaft spillway is a vertical shaft. Water enters the shaft through a surface square-shaped head wall. The head wall is made of cast in-situ reinforced concrete. On the spillway, there are sluice boards for water drainage. A bridge is laid to the head wall.

There are bottom sludge deposits in front of the spillway tower. The deposits measured layer is $1.6 \mathrm{~m}$ thick. Silting and swampiness are also noted at the outlet in the tail water (Fig.1a).

The following basic defects and damages are revealed: head wall principal reinforcement corrosion; local destruction of spillway tower concrete.

\subsubsection{The third stage of cascade}

The third stage of cascade between the ponds No. 3 and No. 4 includes an earth dam, an open controlled overflow spillway in the dam body with a staged water outlet (Fig1.b) and a non-functioning shaft spillway with bottom outlet.

An open staged spillway 3-4 includes: a) head part - water intake in the form of a surface hole, head wall transit part, b) discharge part in the form of a staged outlet, c) end part of the outlet in the form of a water cushion with the bell to reduce specific water flow rate. All the structural elements of the spillway are made of cast in-situ reinforced concrete.

The cascade has 3 stages of about $6.0 \mathrm{~m}$ wide. The stages are made in the form of a water cushion. The distance bars (Fig1.b) across the stage width made of the pipe of 100 $\mathrm{mm}$ in diameter were installed later.

Non-functioning shaft spillway 3-4 was intended for water discharge from the pond No. 3 into the pond No. 4. Measured thickness of the bottom deposits in front of the spillway tower is about $0.5 \mathrm{~m}$.

The following main damages to the spillway 3-4 are revealed: opening of expansion joints, horizontal displacement of the left wall lower area along the expansion joint of up to $40 \mathrm{~mm}$; corrosion of reinforcement in the area of expansion joints opening.

\subsubsection{The fourth stage of cascade}

The fourth stage of cascade between the pond No. 4 and No. 5 includes an earth dam, shaft spillway with bottom outlet (Fig3).

Originally built in 1939, the shaft spillway is wooden. In 1948, the project for restoration of destroyed spillway was developed in three versions: wooden, concrete and reinforced concrete. In 1950, a note on repair and restoration works was written. The accepted version of reinforced concrete spillway was built in 1950 and has been functioning 
till present. The original spillway design, including bridge guard grating, sluice board lifting mechanisms, has been preserved (Fig3).

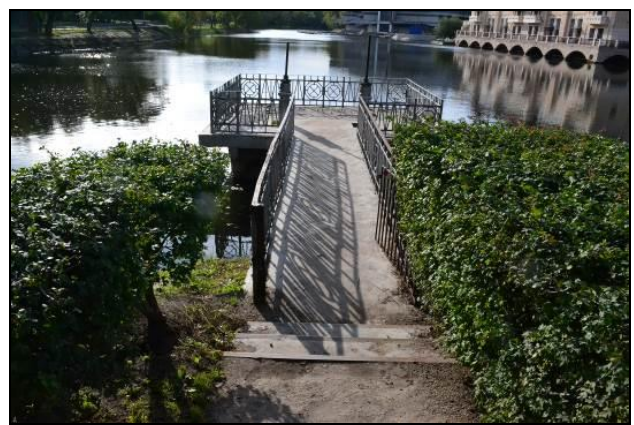

a)

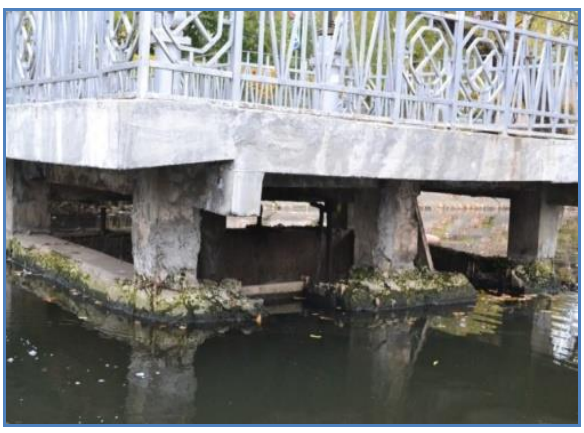

b)

Fig.3. a) General view of the spillway 4-5 on the side of the pond No. 4 head water from the crest of the dam No. 4; b) Shaft spillway of the dam No. 4. Two water inlets. Destroyed concrete of water intake head and bridge supports. Original grating was designed in 1950.

The shaft spillway made of cast in-situ reinforced concrete has a vertical shaft about 3.6 $\mathrm{m}$ high. The spillway head is $4.2 \times 5 \mathrm{~m}^{2}$ in size. Bottom deposits in front of the spillway tower are $0.5 \mathrm{~m}$ thick.

A $13.6 \mathrm{~m}$ long bridge is laid to the spillway. The handrails installed on the bridge correspond to the spillway restoration project dated 1950 .

The following main damages of the spillway 4-5 are revealed (Fig 3):

damage to head reinforced concrete structures: destroyed protective concrete layer, reinforcement corrosion damage of up to $20 \%$; significant damage to the shaft wall upper part concrete with bare reinforcement in certain areas in variable water level zone.

\section{Results}

There are obtained pre-project evaluations of the pond cascade hydraulic engineering structures technical conditions: dams, spillways. The technical condition and level of safe operation for the hydraulic structures are determined according to terminology of the Russian register of hydraulic engineering structures (RRHES). The inspection data, recommendations for reconstruction, restoration of the structures are given in table.1. 
Table 1. Evaluation of structures technical condition and safety level.

\begin{tabular}{|c|c|c|}
\hline Structures & $\begin{array}{l}\text { Technical } \\
\text { condition; } \\
\text { Safety level }\end{array}$ & Recommendations \\
\hline \multicolumn{3}{|c|}{ The 1st stage of cascade: pond No. 1-pond No. 2. Inspection of dam No. 1.} \\
\hline Dam No. 1 & $\begin{array}{l}\text { Normal; } \\
\text { Normal }\end{array}$ & Repair of damaged grassing in certain areas. \\
\hline $\begin{array}{l}\text { Overflow } \\
\text { spillway } 1-2\end{array}$ & $\begin{array}{l}\text { Normal; } \\
\text { Normal }\end{array}$ & $\begin{array}{l}\text { 1. Repair of the column shears of the sluice boards. } \\
2 \text {. Discharge of water from the roadway beyond the } \\
\text { bridge, disposing of rain and melt water on the lower slope } \\
\text { away from the structure. } \\
\text { 3. Current repair of the bridge slab lower surface (on the } \\
\text { humidification section). }\end{array}$ \\
\hline \multicolumn{3}{|c|}{ The 2nd stage of cascade: pond No. 2 -pond No. 3. Inspection of dam No. 2} \\
\hline Dam No. 2 & $\begin{array}{l}\text { Satisfactory; } \\
\text { Unsatisfactory }\end{array}$ & $\begin{array}{l}\text { 1. Repair of the road surface along the dam crest. } \\
\text { 2. Repair of the scours and grassing on the dam lower } \\
\text { slope. }\end{array}$ \\
\hline $\begin{array}{l}\text { Shaft spillway } \\
2-3\end{array}$ & $\begin{array}{l}\text { Unsatisfactory; } \\
\text { low }\end{array}$ & Overhaul of spillway with replacement of the head wall. \\
\hline \multicolumn{3}{|c|}{ The 3rd stage of cascade: pond No. 3 - pond No. 4. Inspection of dam No. 3} \\
\hline Dam No. 3 & $\begin{array}{l}\text { Unsatisfactory; } \\
\text { Low, near to } \\
\text { unsatisfactory }\end{array}$ & $\begin{array}{l}\text { 1. Repair of the road surface along the dam crest. } \\
\text { 2. Repair of the scours and grassing on the dam lower } \\
\text { slope. }\end{array}$ \\
\hline $\begin{array}{l}\text { Overflow } \\
\text { spillway 3-4 }\end{array}$ & $\begin{array}{l}\text { Satisfactory; } \\
\text { Low }\end{array}$ & $\begin{array}{l}\text { Repair of structures in the damaged areas with a reliable } \\
\text { design of expansion joints in the cascade walls. }\end{array}$ \\
\hline $\begin{array}{l}\text { Spillway } \\
\text { 3-4 (inactive) }\end{array}$ & $\begin{array}{l}\text { Unsatisfactory; } \\
\text { Unsatisfactory }\end{array}$ & Overhaul of spillway. \\
\hline \multicolumn{3}{|c|}{ The 4th stage of cascade: pond No. 4 -pond No. 5. Inspection of dam No. 4} \\
\hline $\begin{array}{l}\text { Spillway } \\
4-5\end{array}$ & $\begin{array}{l}\text { Unacceptab } \\
\text { le; } \\
\text { Dangerous }\end{array}$ & $\begin{array}{l}\text { Overhaul with replacement of the head wall and bridge } \\
\text { structure. }\end{array}$ \\
\hline
\end{tabular}

\section{Discussion}

The pre-project evaluations of the pond cascade hydraulic engineering structures technical inspection, analysis of hydraulic structures operation projects have been transferred to develop a project for adaptation of the sightseeing attraction VSHV-VDNH-VVC - zone "VDNH landscaped park" located at the address: 119 Mira avenue, Moscow to modern use as part of the cultural heritage territory.

\section{Conclusions}

Numerous pre-project evaluations of the park structure conditions, systematization of structure operation projects, retrospective analysis of architectural and design approaches to designing and modeling of the exhibition complex is just a part of a large-scale project for 
reconstruction of the urban environment "VSHV-VDNH-VVC" - zone "VDNH landscaped park" which caters to the needs of urban community regarding arrangement of favorable living space and sustainable development of Moscow.

\section{References}

1. A.F. Zhukov, Architecture of the VSKhV (Gos. Izdat. Lit. po Story. i Arh., Moscow, 1955)

2. A.N. Zinov'ev, Ensemble of the VSKhV: architecture and construction (PNB print, Moscow, 2014)

3. A.V. Boev, History of the awards of the country's main exhibition VSKhV-VDNKh, (Pozdnyshev, Kiev, 2007)

4. Official site of VDNKh http://vdnh.ru/en/

5. Russian State Standard GOST 19185-73 Hydraulic engineering. Basic concepts. Terms and definitions

6. Russian State Standard SP 39.13330.2012 Rock fill dams.

7. Russian State Standard SP 58.13330.2012 Hydraulic Structures. Basic statements

8. Russian State Standard GOST 26966-86 Water intake and outlet works and gates. Terms and definitions

9. Russian State Standard GOST R 54257-2010 Reliability of structural elements and foundations. Basic provisions and requirements.

10. M.A. Sokolova, Architecture and Construction of Russia, 4(224), 60 (2017)

11. V.A. Tsvetnov, Architecture and Construction of Russia, 1(221), 106, (2017)

12. N.A. Saprykina, Formation of an eco-sustainable future environment: Theory Practice Perspectives (Palmarium Academic Publishing, Saarbrücken, 2017)

13. A.V. Ikonnikov, The artistic language of architecture (Iskusstvo, Moscow, 1985)

14. A.V. Tatarchenko, Architecture and Construction of Russia, 4(224), 94 (2017)

15. Russian State Standard SP 13-102-2003 Rules of inspection of bearing structures of building and facilities

16. Russian State Standard GOST R 53778-2010 Buildings and constructions. Rules of inspection and monitoring of the technical condition

17. Russian State Standard SP 20.1330.2011 Loads and impacts

18. Russian State Standard SP 15.13330.2011 Masonry and reinforced masonry structures

19. Russian State Standard SNiP 52.01-2003 Concrete and reinforced concrete structures. 